\title{
KONSTRUKSI KOSUBORDINASI DALAM BAHASA INDONESIA (PERSPEKTIF LINGUISTIK FUNGSIONAL)
}

\author{
Construction of Cosubordination in Indonesian Language \\ (Functional Linguistic Perspective)
}

\author{
Miftahulkhairah Anwar \\ Universitas Negeri Jakarta \\ miftahulkhairah@unj.ac.id
}

\begin{abstract}
Abstrak
Tulisan ini akan menyajikan sebuah paparan tentang konstruksi kosubordinasi bahasa Indonesia dari sudut pandang fungsionalisme van Valin. van Valin membagi hubungan klausa ke dalam tiga jenis: koordinasi, subordinasi, dan kosubordinasi. Kosubordinasi merupakan rangkaian aktivitas berurutan dari suatu konstruksi yang dilakukan oleh partisipan. Hubungan ini menyerupai koordinasi, tetapi tidak dapat berdiri sendiri sebagai suatu klausa bebas karena klausa yang satu terikat pada yang lain. Hubungan ini menghasilkan relasi semantik. Metode penelitian yang digunakan dalam penelitian ini adalah metode kualitatif deskriptif dengan data yang bersumber dari Kompas periode Januari dan Maret 2018. Berdasarkan penelusuran terhadap data, ditemukan beberapa relasi makna yang terdapat dalam konstruksi kosubordinasi bahasa Indonesia, yaitu relasi bermakna tujuan, fase, wacana tidak langsung, jussive (ekspresi perintah, permintaan, atau tuntutan), penyikapan awal, kognisi, dan persepsi tidak langsung.
\end{abstract}

Kata-kata kunci : Linguistik Fungsional, Konstruksi Kosubordinasi, Bahasa Indonesia

\begin{abstract}
This paper attempts to present an explanation of the cosubordination construction of Indonesian language in the van Valine's functionalism perspective. van Valine divides the clause relationship into three types: coordination, subordination, and cosubordination. Cosubordination is a series of sequential activities of a construction carried out by participants. This relationship resembles coordination, but cannot stand alone as a free clause because one clause is bound to another. This relationship produces semantic relations. The research method used in this study is descriptive qualitative method based on data resources from Kompas on January and March, 2018. Based on data searching, found several meaningful relations found in the cosubordinated construction of Indonesian language, namely the meaning of the purposive, phase, indirect discourse, jussive (command expression, request, or demand), propositional attitude, cognition, and indirect perception.
\end{abstract}

Keywords: Functional Linguistics, Cosubordinate Construction, Indonesian Language 
How to Cite: Anwar, Miftahulkhairah. (2019). Konstruksi Kosubordinasi dalam Bahasa Indonesia (Perspektif Linguistik Fungsional), Ranah: Jurnal Kajian Bahasa, 8 (1), 1-17. doi: https://doi.org/10.26499/rnh.v8i1.6947

\section{PENDAHULUAN}

Teorisasi ilmu bahasa mutakhir dapat dipetakan menjadi dua mazhab besar, yakni orientasi formalisme versus fungsionalisme. Teori formalisme diwakili oleh Tata Bahasa Transformatif Generatif Chomsky, sedangkan teori fungsionalisme diwakili oleh Halliday dan van Valin. van Valin, sebagai pencetus konsep Fungsionalisme Role and Referent Grammar (RRG) memandang bahasa sebagai suatu sistem tindak komunikasi sosial. Oleh karena itu, analisis fungsi komunikatif struktur gramatika memainkan peran penting dalam kajian bahasa. Struktur gramatikal hanya dapat dipahami dengan mengacu pada fungsi semantik dan komunikatif. Bagi van Valin (1997: 319-320), bahasa adalah sistem bentuk untuk menyampaikan makna-makna dalam komunikasi (Anwar dan Sakura, 2014: 1-6; Anwar 2010: 2).

Tulisan ini akan menyajikan sebuah paparan tentang konstruksi kosubordinasi bahasa Indonesia dari sudut pandang fungsionalisme van Valin. Secara umum, para ahli membagi hubungan klausa bahasa Indonesia ke dalam dua jenis: koordinasi dan subordinasi (Parera, 2002:49; Achmad, 2002: 131-15; Alwi dkk., 2003: 385-388; Putrayasa, 2007: 55-62; Ramlan, 2008: 40-62; Arifin dan Junaiyah, 2009: 41-53; Chaer, 2009: 168). Tata Bahasa Baku Bahasa Indonesia Edisi Keempat (2017: 454-457) menggunakan konsep yang sama, tetapi dengan istilah berbeda, yaitu istilah majemuk untuk hubungan setara dan istilah kompleks untuk hubungan bertingkat.

Hubungan koordinasi menggabungkan dua klausa atau lebih yang masingmasing mempunyai kedudukan yang setara dalam struktur konstituen kalimat. Hubungan antarklausa-klausanya tidak membentuk hierarki karena klausa yang satu bukanlah konstituen dari klausa yang lain. Dalam hubungan koordinasi, masing-masing klausa memiliki kedudukan yang sama dan dapat dihubungkan oleh konjungtor atau kata penghubung, seperti atau, tetapi, serta, lalu, kemudian, lagipula, padahal, sedangkan, baik, mampu, tidak, bukan, dan melainkan .

Sementara itu, hubungan subordinasi merupakan gabungan dua klausa atau lebih yang salah satu klausanya menjadi bagian dari klausa yang lain. Klausa-klausa yang memiliki hubungan subordinasi ini tidak mempunyai kedudukan yang setara. 
Konjungtor yang menghubungkan kalimat subordinatif menggunakan konjungtor waktu, syarat, pengandaian, tujuan, konsesif, pembandingan, sebab atau alasan, cara dan konjungtor alat.

Pada kenyataannya, hubungan antarklausa tidak hanya berjenis koordinasi dan subordinasi, tetapi ada pula hubungan yang terbentuk secara kosubordinasi. Bagi van Valin, hubungan kosubordinasi adalah hubungan yang menyerupai koordinasi, tetapi masing-masing klausanya tidak dapat berdiri sendiri sebagai suatu klausa bebas karena klausa yang satu terikat pada klausa yang lain (Firdaus: 2018).

Berdasarkan hasil penelusuran, penelitian mengenai konstruksi kosubordinasi dalam bahasa Indonesia belum pernah diteliti. Penelitian yang berkaitan dengan konstruksi kosubordinasi adalah verba serial (Serial Verba Constructions). Caesar (2016:32 -43) dalam penelitiannya berjudul Serial Verb Constructions in Dangme menjelaskan sifat dan karakterisitik konstruksi verba serial pada bahasa Dangme, sebuah bahasa yang dituturkan di wilayah Ghana Tenggara. Hasil penelitian tersebut menunjukkan bahwa konstruksi verba serial pada bahasa Dangme memiliki beberapa tipe fungsional, seperti kausatif, SVC komparatif, SVC direktif, pertanyaan, dan fokus SVC. Kemiripan kajian konstruksi subordinasi dengan konstruksi verba serial terdapat pada unsur predikat yang memiliki lebih dari satu verba. Struktur verba serial merupakan struktur predikatif dengan verba utama lebih dari satu.

Selain itu, penelitian ini juga memiliki kaitan dengan hubungan subordinasi dan koordinasi. Belyaev (2015:267-326) dalam penelitiannya yang berjudul Systematic Mismatches: Coordination and Subordination at Three Levels of Grammar menjelaskan hubungan antara subordinasi dan koordinasi. Menurutnya, satu-satunya perbedaan semantik antara koordinasi dan subordinasi adalah bahwa koordinasi memperkenalkan hubungan wacana antara tindak tutur, sedangkan subordinasi memperkenalkan predikat yang menghubungkan dua proposisi dalam tindak tutur yang sama.

Konstruksi kosubordinasi merepresentasikan suatu relasi makna. Relasi makna ini tercermin dari rantaian peristiwa yang membangun konstruksi kalimat. Dengan menggunakan kualitatif deksriptif, tulisan ini akan memuat deskripsi tentang konstruksi kosubordinasi dan relasi semantiknya. Tulisan ini diharapkan dapat menambah variasi kajian bahasa Indonesia serta memberi kontribusi yang signifikan bagi pengembangan bahasa Indonesia. 


\section{LANDASAN TEORI}

Menurut van Valin (2001:4; 2005:2-3), struktur klausa itu berlapis (layered structure of the clause/LSC), terdiri dari (1) nucleus yang berisi predikator, (2) core yang berisi nucleus dan argument, dan (3) periphery yang berisi keterangan. Nucleus dan core disebut lapisan inti, sedangkan keterangan disebut periphery atau lapisan pendukung. Antara klausa yang satu dengan klausa yang lain saling berhubungan. Valin menyebut hubungan ini dengan istilah nexus atau dalam bahasa Indonesia disebut majemuk.

Umumnya, ahli bahasa membagi hubungan antarklausa ke dalam dua jenis: koordinasi dan subordinasi. van Valin (2005:78) menambahkan satu hubungan antarklausa, yaitu hubungan kosubordinasi (cosubordination). Dengan demikian, hubungan antarklausa (nexus) dipetakan menjadi: (1) koordinasi, (2) subordinasi, dan (3) kosubordinasi.

Hubungan koordinasi menggabungkan dua klausa atau lebih yang masingmasing mempunyai kedudukan setara dalam struktur kalimat. Artinya, semua klausa tersebut merupakan klausa inti, tidak membentuk hierarki karena klausa yang satu bukanlah bagian dari klausa yang lain. Karena itu, hubungan klausa yang terbentuk secara koordinatif.

Hubungan subordinasi menunjukkan hubungan yang hierarkis, yakni menggabungkan dua klausa atau lebih secara bertingkat, ada yang berfungsi sebagai klausa utama dan ada yang berfungsi sebagai klausa bawahan. Karena itu, hubungan yang demikian disebut pula dengan majemuk bertingkat. Penggunaan kata penghubung yang bersifat subordinatif menyebabkan klausa yang satu menjadi bagian dari klausa yang lain. Biasanya, klausa utama disebut dengan klausa bebas, sedangkan klausa bawahan disebut dengan klausa terikat. Berikut adalah contoh dari hubungan klausa tersebut (van Valin, 2005: 8-9).

(1) 'He is coming, but I am not afraid.'

Dia akan datang, tetapi saya tidak takut (Koordinasi)

(2) 'I came whistling'. 'saya datang sambil bersiul'. (Kosubordinasi)

(3) Because I am Whistling, the dog will come.

Karena saya bersiul, anjing itu akan datang (Subordinasi) 
Hubungan kosubordinasi adalah hubungan yang menyerupai koordinasi, tetapi masing-masing klausanya tidak dapat berdiri sendiri sebagai suatu klausa bebas karena klausa yang satu terikat pada klausa yang lain (van Valin, 2001:9; Anwar dan Sakura, 2014:190-191). Perhatikan contoh berikut ini!

(4)Sam duduk memainkan gitar.

(5)Harry keluar membeli beberapa minuman.

Kalimat (4) terdiri dari dua klausa, yaitu Sam duduk dan (Sam) memainkan gitar. Kedua klausa ini terhubung secara kosubordinasi, artinya klausa pertama Sam duduk seakan-akan sejajar dengan klausa kedua memainkan gitar, tetapi klausa kedua tak bisa dilepaskan dari klausa pertama (tak dapat berdiri sendiri) karena secara struktur, klausa kedua memainkan gitar merupakan bagian dari klausa pertama Sam duduk. Keduanya pun tidak dihubungkan oleh konjungsi.

Hal ini juga terjadi pada kalimat (5). Kalimat (5) terdiri dari dua klausa, yaitu Harry keluar dan (Harry) membeli beberapa minuman. Keduanya pun terhubung secara kosubordinasi tanpa konjungsi. Klausa pertama Harry keluar tampak sejajar dengan klausa kedua membeli beberapa minuman, tetapi keduanya bersifat hierarkis karena klausa kedua merupakan bagian dari klausa pertama.

Beberapa contoh tersebut menunjukkan bahwa kosubordinasi merupakan rangkaian aktivitas dari suatu konstruksi. Tulisan ini menitikberatkan relasi semantik kosubordinasi dari rangkaian aktivitas dari suatu konstruksi.

Menurut van Valin (2005: 18-19), hubungan antarklausa baik koordinasi, subordinasi, maupun kosubordinasi memuat relasi makna yang disebut relasi semantik interklausa. Konsep dasar relasi semantik interklausa itu dipaparkan sebagai berikut.

1. Causative I (Kausatif I): penyebab terjadinya suatu keadaan secara langsung akibat dari keadaan lain, biasanya berupa peristiwa, kejadian, atau tindakan. Contoh: Max painted the door green, Larry pushed the window open (Max mengecat pintu sehingga menjadi hijau, Larry mendorong jendela sehingga terbuka).

2. Phase (Fase): verba terpisah yang mendeskripsikan permukaan keadaan peristiwa-peristiwa duniawi, terutama pada permulaannya, kesudahannya, atau keberlanjutannya. Contoh: Christ started crying, Fred kept singing, Hari 
finished writing the chapter (Christ mulai menangis, Fred terus menyanyi, Hari telah selesai menulis judul).

3. Modifying subevents (Pengubahan sub-kejadian/peristiwa) yang meliputi halhal berikut.

a. Manner: cara bagaimana gerakan sebuah kajadian dilaksanakan/diselesaikan. Contoh: Bill entered the room skipping (Bill telah memasuki ruangan dengan cara melompat.

b. Motion: gerakan yang menyertai tindakan lainnya. Contoh: speak while going up

c. Position: cara berdiri/sikap saat melakukan tindakan. Contoh: Dana sat reading a newspaper (Dana membaca koran berdiri)

d. Means: peralatan yang digunakan untuk melakukan tindakan. Contoh: Sam opened the box by slicing it with a knife (Sam membuka kotak dengan mengirisnya menggunakan pisau)

4. Psych-action: disposisi mental terkait dengan tindakan yang mungkin dialami oleh partisipan (pelibat) pada sebuah peristiwa. Contoh: Max decided to leave, Sally forgot to open the window.

5. Purposive (maksud atau tujuan): suatu tindakan yang dilakukan dengan menekankan terwujudnya kejadian lain dalam suatu peristiwa. Contoh: Juan went to the store to buy the milk, Susan forgot to open the window.

6. Jussive: ekspresi perintah, permintaan, atau tuntutan. Contoh: Pat asked the student toleave, The king ordered the troops to attack the city (Pat meminta siswa untuk pergi/beranjak, Raja menyuruh pasukan menyerang kota).

7. Causative 2 (Kausatif 2): menyebabkan terjadinya satu keadaan dari peristiwaperistiwa melalui tindakan atau kejadian yang berbeda. Contoh: Fred forced Max to paint the the table (Fred memaksa Max untuk mengecat meja).

8. Direct perseption (Persepsi Langsung): Deduksi beberapa tindakan, kejadian, atau situasi yang tak bermediasi melalui indera. Contoh: Rex saw the child open the door, Yolanda heard the guest arrive (Rex melihat anak-anak membuka pintu, Yolanda mendengar tamu tiba). 
9. Indirect perseption (Perpsepsi tidak langsung): deduksi dari beberapa tindakan, kejadian, atau situasi dari buktinya. Contoh: (melihat ke bangku yang kosong) I see that John has gone early (aku melihat John pulang dini).

10. Propositional attitude (sikap pendahuluan): ekspresi dari sikap pelibat, keputusan, atau pendapat terkait dengan kejadian peristiwa. Contoh: Carl believe that UFOs are a menace to the earth, Paul consider Carl to be fool, Most fans want very much for they team to win (Carl percaya bahwa UFO adalah sebuah ancaman bagi bumi, Paul menganggap Carl tidak waras, kebanyakan penggemar sangat menginginkan tim mereka menang).

11. Cognition (Kognisi): ekspresi pengetahuan atau aktivitas mental. Contoh: Aaron knows that the earth is round, George is thinking about Madelein's refusal to go out with him (Aaron tahu bahwa bumi adalah bulat, George berpikir bahwa Madelein menolak untuk pergi bersamanya).

12. Indirect discourse (diskursus langsung): ekspresi atau pernyataan yang direkam/dilaporkan. Contoh: Frank said that his friends were corrupt (Frank menyatakan bahwa teman-temannya telah korupsi).

13. Direct discourse (diskursus langsung): Kutipan langsung suatu kejadian dalam bentuk ucapan/pernyataan. Contoh: Frank said, "My friends are corrupt" (Frank berkata: 'teman-temanku korupsi”).

14. Circumstancess (Keadaan-keadaan): mengenai ruang atau parameter waktu kejadian. Contoh: Sam talked to Sally at the library after work.

15. Reason (Alasan): motivasi atau sebab tindakan atau sebab kejadian. Contoh: The baby cried, because she was hungry.

16. Conditional (Kondisional): ekspresi tentang konsekuensi yang akan diambil dari kondisi-kondisi yang ada pada keadaan tertentu dalam suatu peristiwa. Contoh: If it rains, we won't be able to have picnic, Were Fred to leave now, he would look like a fool (bila hujan, kita tidak akan dapat melakukan piknik, bila Fred pergi sekarang, ia akan terlihat dungu/ seperti tidak waras)

17. Concessive (mengizinkan/mudah): isi dari klausa utama berlangsung secara tidak diharapkan, memberikan isi klausa subordinasi. Contoh: Bill made it to work, even though it was snowing heavily (Bill membuatnya bekerja, namun demikian hujan salju sedemikian lebat). 
18. Temporal (Pembagian Waktu):

a. Keadaan-keadaan simultan: suatu keadaan yang tidak saling berhubungan, contoh: Max danced and Susan played the piano, Kim had chicken pox and at the same time Leslie had the measles (Max berdansa dan Susan bermain piano, Kim kena cacar air dan pada saat yang sama Leslie terkena campak)

b. Rangkaian keadaan peristiwa: suatu keadaan mengikuti keadaan yang lain secara sementara, baik secara bersamaan ataupun tidak, contoh: Tyronne talked to Tanisha, and Yolanda chatted with Kareem.

\section{METODE PENELITIAN}

Studi ini dilakukan dengan mengikuti prinsip kerja penelitian deskriptif dan rancangan kualitatif. Data dalam penelitian ini adalah satuan lingual kebahasaan yang menunjukkan konstruksi kalimat bertipe kosubordinasi. Sumber data dalam studi ini adalah 10 rubrik yang terdapat di dalam Kompas, yaitu rubrik politik, ekonomi, opini, humaniora, nusantara, metro, internasional, tokoh, multimedia, dan gaya hidup, periode 30 Januari 2018 dan 9 Maret 2018. Penentuan data ini dilakukan secara purposive sampling atas dasar pengamatan pada aspek kuantitas yang ditemukan di dalam sumber data tersebut. Adapun metode pengumpulan data yang digunakan adalah metode simak dengan teknik catat, yaitu mencatat data lingual kosubordinasi ke dalam kartu data. Rangkaian kegiatan analisis dilakukan melalui prosedur sebagai berikut: 1) reduksi data yang meliputi pengidentifikasian, pengklasifikasian, dan pengkodean tentang satuan lingual berstruktur kosubordinasi; 2) analisis data ujaran yang memuat kosubordinasi dengan menggunakan tabel instrumen analisis data yang disusun berdasarkan paradigma linguistik fungsional; 3) verifikasi terhadap penafsiran data.

\section{PEMBAHASAN}

Bagi van Valin (2005 : 21-23), hubungan kosubordinasi adalah hubungan yang menyerupai koordinasi, tetapi masing-masing konstruksi itu tidak dapat berdiri sendiri sebagai suatu klausa bebas karena klausa yang satu terikat pada yang lain. Oleh karena itu, hubungan tersebut menghasilkan relasi semantik, yang oleh Valin disebut sebagai relasi semantik interklausa. Berdasarkan penelusuran terhadap data, ditemukan beberapa relasi 
makna yang terdapat dalam konstruksi kosubordinasi bahasa Indonesia, di antaranya (1) tujuan, (2) fase, (3) wacana tidak langsung, (4) jussive (ekspresi perintah, permintaan, atau tuntutan), (5) sikap awal, (6) kognisi, dan (7) persepsi tidak langsung. Berikut ini adalah paparan dari setiap relasi semantik tersebut.

\section{Hubungan Purpossive (Tujuan)}

Relasi ini menunjukkan adanya suatu tujuan atau maksud dari apa yang disebut pada aktivitas pertama. Aktivitas pertama dilakukan dengan tujuan terwujudnya aktivitas lain dalam peristiwa itu. Dari penelusuran data, ditemukan beberapa deret verba yang memuat hubungan tujuan dalam bahasa Indonesia. Deret verba tersebut adalah bertujuan meningkatkan, berusaha membungkam, berkontribusi mengatasi, membantu menciptakan, mencoba menenangkan, berusaha menggali, berencana mengembangkan, berupaya menjaga, berusaha menggali, membantu mendeteksi, bertujuan mengalihkan, diminta menunggu, disarankan datang. Hubungan tujuan ini ditunjukkan oleh pertautan aktivitas pada verba pertama dan kedua. Verba kedua merupakan tujuan dari apa yang disebutkan pada verba pertama. Konstruksi tersebut berjenis kosubordinasi karena aktivitas pertama dan kedua tampak sejajar, tetapi aktivitas kedua merupakan bagian dari aktivitas pertama. Dari keseluruhan data yang dianalisis, hubungan tujuan merupakan relasi yang paling banyak digunakan, yaitu sebesar $23,95 \%$. Oleh karena itu, verba bahasa Indonesia yang berpotensi membentuk konstruksi kosubordinasi bermakna hubungan tujuan adalah bertujuan, berusaha, berkontribusi, berencana, membantu, mencoba, berupaya, diminta, disarankan.

Berikut ini merupakan contoh relasi bermakna tujuan atau maksud dalam konstruksi kosubordinasi bahasa Indonesia.

(6) Komisi II pada dasarnya bertujuan meningkatkan produktivitas PNS.

(7) Kalian berusaha membungkam gerakan ini.

(8) Banyak pakar berbagai bidang yang bisa berkontribusi mengatasi soal gizi itu.

(9) Sementara itu, Hue Lightstrip Plus ikut membantu menciptakan suasana pencahayaan yang tepat dan menyeluruh hingga ke bawah rak, lemari, dan furnitur lainnya.

(10) Pihak kepolisian bersama masyarakat mencoba menenangkan para pekerja yang kesurupan.

(11) Majelis Hakim juga berusaha menggali keputusan Gunawan.

(12) Saya berencana mengembangkan usaha dengan modal uang pesangon dan dana JHT BPJS Ketenagakerjaan.

(13) Saya diminta menunggu maksimal lima hari kerja untuk proses pencairan. 
(14) Karena antrean sudah panjang, saya disarankan datang lagi keesokan harinya atau mengajukan pencairan JHT secara online.

Contoh (6)-(14) memuat adanya konstruksi kosubordinasi yang ditunjukkan oleh adanya deret verba: bertujuan meningkatkan, berusaha membungkam, berkontribusi mengatasi, membantu menciptakan, mencoba menenangkan, berusaha menggali, berencana mengembangkan, diminta menunggu, disarankan datang. Deret verba ini menghasilkan hubungan bermakna tujuan. Hubungan ini ditunjukkan oleh pertautan aktivitas pada verba pertama dan kedua. Verba kedua merupakan tujuan dari apa yang disebutkan pada aktivitas pertama.

Pada contoh (6), aktivitas kedua, meningkatkan produktivitas PNS merupakan tujuan dari apa yang disebutkan pada aktivitas pertama, Komisi II pada dasarnya bertujuan. Meskipun seakan terlihat sejajar, tetapi aktivitas kedua merupakan bagian dari aktivitas pertama. Aktivitas kedua pada contoh (7) membungkam gerakan ini merupakan tujuan dari apa yang disebutkan pada aktivitas pertama, Kalian berusaha. Aktivitas kedua pada contoh (8), mengatasi soal gizi itu merupakan tujuan dari apa yang disebutkan pada aktivitas pertama, Banyak pakar berbagai bidang yang bisa berkontribusi. Aktivitas kedua, pada contoh (9) menciptakan suasana pencahayaan yang tepat merupakan tujuan dari apa yang disebutkan pada aktivitas pertama, Hue Lightstrip Plus ikut membantu. Aktivitas kedua pada contoh (10) menenangkan para pekerja yang kesurupan merupakan tujuan dari apa yang disebutkan pada aktivitas pertama, Pihak kepolisian bersama masyarakat mencoba. Aktivitas kedua pada contoh (11) menggali keputusan Gunawan menunjukkan tujuan dari apa yang disebutkan pada aktivitas pertama, Majelis Hakim juga berusaha. Aktivitas kedua pada contoh (12) mengembangkan usaha dengan modal uang pesangon dan dana JHT BPJS Ketenagakerjaan merupakan tujuan dari apa yang disebutkan pada aktivitas pertama, Saya berencana. Aktivitas kedua pada contoh (13) menunggu maksimal lima hari kerja untuk proses pencairan merupakan tujuan dari apa yang disebutkan pada aktivitas pertama Saya diminta. Aktivitas kedua pada contoh (14) datang lagi keesokan harinya merupakan tujuan dari apa yang disebutkan pada aktivitas pertama Saya disarankan.

\section{Hubungan Indirect Discourse (Wacana Tidak Langsung)}

Hubungan wacana tidak langsung terdapat dalam suatu pernyataan yang dinyatakan, dilaporkan, atau direkam. Hubungan ini tampak pada deret verba yang 
menunjukkan pertautan antara aktivitas pertama dan kedua. Verba pertama menunjukkan aktivitas menyatakan, melaporkan, atau merekam yang dilakukan oleh partisipan, sedangkan verba kedua menunjukkan apa yang dinyatakan, dilaporkan, atau direkam oleh partisipan. Hal ini menunjukkan bahwa kalimat tersebut memuat hubungan wacana tidak langsung yang seakan-akan terlihat setara, tetapi aktivitas kedua tidak dapat dilepaskan dari aktivitas pertama. Dari penelusuran data, ditemukan beberapa deret verba yang memuat hubungan wacana tidak langsung dalam bahasa Indonesia. Deret verba tersebut adalah menyatakan bersedia, disebutkan menimbulkan, dinyatakan memenuhi. Dari keseluruhan data yang dianalisis, hubungan wacana tidak langsung ditemukan sebanyak 12,5\%.

Berikut ini beberapa contoh hubungan wacana tidak langsung yang terdapat di dalam rubrik Kompas.

(15)Dalam pertemuan itu, Jong Un juga menyatakan bersedia melakukan dialog dengan AS terkait peluncuran nuklir.

(16)Dampak gempa disebutkan menimbulkan kerusakan parah di seluruh penjuru kota.

(17)Tanggal 15 Februari, saya ke kantor cabang Mampang dan semua dokumen itu dinyatakan memenuhi syarat.

Aktivitas bersedia melakukan dialog dengan AS terkait peluncuran nuklir pada contoh (15) merupakan suatu pernyataan yang diungkapkan oleh Jong Un pada aktivitas pertama. Hal ini menunjukkan bahwa kalimat tersebut memuat hubungan wacana tidak langsung yang seakan-akan terlihat setara, tetapi aktivitas kedua tidak bisa dilepaskan dari aktivitas pertama. Hubungan ini ditunjukkan oleh adanya deret verba menyatakan bersedia. Hubungan ini juga tampak di dalam contoh kalimat (16) dan (17). Aktivitas menimbulkan kerusakan parah di seluruh penjuru kota pada contoh (16) dan aktivitas memenuhi syarat pada contoh (17) merupakan sesuatu yang dilaporkan.

\section{Hubungan Fase}

Hubungan fase mendeskripsikan suatu peristiwa mulai dari permulaannya, kesudahannya, atau keberlanjutannya. Peristiwa itu terhubung secara kosubordinasi, artinya aktivitas pertama seakan-akan sejajar dengan aktivitas kedua, tetapi aktivitas kedua tak bisa dilepaskan dari aktivitas pertama (tak dapat berdiri sendiri) karena secara struktur, aktivitas kedua merupakan bagian dari aktivitas pertama. Konstruksi ini menghasilkan hubungan fase yang menunjukkan bahwa aktivitas kedua dan seterusnya merupakan perkembangan lebih lanjut dari aktivitas pertama. Dari keseluruhan data 
yang dianalisis, hubungan fase ditemukan sebanyak 10,41 \%. Berikut ini beberapa contoh relasi semantik fase.

(18)Panglima TNI Marsekal Hadi Tjahjanto dalam suratnya ke ketua pansus tertanggal 8 Januari 2018 mengusulkan mengganti judul RUU dan definisi terorisme.

(19)Bahkan, warga sekitar berteriak meminta bantuan.

(20) Warga di sekitar daerah itu menyamar mengenakan baju tentara.

(21)Ia berjanji akan memulai mengirim konvoi bantuan kemanusiaan ke Ghouta Timur jika pertempuran mulai reda.

Konstruksi (18) terdiri dari dua aktivitas, yaitu Panglima TNI Marsekal Hadi Tjahjanto mengusulkan dan (Panglima TNI Marsekal Hadi Tjahjanto) mengganti judul $R U U$ dan definisi terorisme. Keduanya terhubung secara kosubordinasi, artinya aktivitas pertama seakan-akan sejajar dengan aktivitas kedua, tetapi aktivitas kedua tak bisa dilepaskan dari aktivitas pertama (tak dapat berdiri sendiri) karena secara struktur, aktivitas kedua mengganti judul RUU dan definisi terorisme merupakan bagian dari aktivitas pertama Panglima TNI Marsekal Hadi Tjahjanto mengusulkan. Konstruksi ini menghasilkan hubungan fase yang menunjukkan bahwa aktivitas mengganti merupakan perkembangan lebih lanjut dari aktivitas mengusulkan.

Sama halnya dengan kalimat (18), kalimat (19) juga mengadung hubungan fase yang menunjukkan bahwa aktivitas warga sekitar meminta bantuan merupakan perkembangan lebih lanjut dari aktivitas warga sekitar berteriak. Kalimat (20) juga mengandung hubungan fase yang menunjukkan bahwa aktivitas warga di sekitar daerah itu mengenakan baju tentara merupakan perkembangan lebih lanjut dari aktivitas warga di sekitar daerah itu menyamar. Hubungan fase pada kalimat (21) pun tampak dari keberlanjutan aktivitas dari verba memulai ke mengirim. Keduanya terhubung secara kosubordinasi, artinya aktivitas pertama seakan-akan sejajar dengan aktivitas kedua, tetapi aktivitas kedua tak bisa dilepaskan dari aktivitas pertama.

Contoh (18)—(21) yang memuat hubungan fase ditunjukkan oleh penggunaan verba pada aktivitas pertama, yaitu mengusulkan, berteriak, menyamar, dan memulai. Verba ini berpotensi membentuk konstruksi deret verba: mengusulkan mengganti, berteriak meminta, menyamar mengenakan, memulai mengirim. Deret verba inilah yang kemudian menghasilkan konstruksi kosubordinasi bermakna fase dalam bahasa Indonesia. 


\section{Jussive: Hubungan Ekspresi Perintah, Permintaan, dan Tuntutan}

Hubungan jussive adalah relasi makna yang memuat ekspresi perintah, permintaan, larangan, atau tuntutan yang terdapat dalam suatu kalimat. Dari penelusuran data, ditemukan beberapa verba bahasa Indonesia yang berpotensi membentuk konstruksi kosubordinasi bermakna hubungan jussive sebesar 14,6\%. Verba tersebut diantaranya menyuruh, membantah, melarang, mengancam, dilarang, didakwa, dan ditantang. Deret verba yang dihasilkan adalah menyuruh mengubah, membantah menerima, melarang memungut, mengancam mengubah, dilarang makan, dilarang menerima, didakwa menyiapkan, ditantang mengeksplorasi. Berikut ini beberapa contoh relasi jussive yang terdapat di dalam rubrik Kompas.

(22) Dialah yang menyuruh mengubah aturan yang telah disepakati.

(23) Begitu juga dengan Direktur Jalan Bebas Hambatan Direktorat Jenderal Bina Marga Subagyo yang membantah menerima uang dari Kepala Balai Pelaksanaan Jalan Nasional (BPJN) IX Provinsi Maluku dan Maluku Utara (Malut) Amran HI Mustary.

(24) Sebagai pejabat, ia melarang memungut iuran kebersihan dari pengurus RT dan RW.

(25) "Bagaima disebut kriminal? Teroris itu, kan, mengancam mengubah ideologi Pancasila dan tentara ini pembela ideologi Negara yang bertanggung jawab.

(26) Aparatur Sipil Negara (ASN) dilarang menerima honor dari pihak swasta.

(27) Bimanesh didakwa menyiapkan catatan medis palsu agar Novanto bisa dirawat.

(28) Presiden Direktur Shell Indonesia Darwin Silalahi mengatakan, pada kompetisi berformat festival yang terbuka bagi umum itu, tim-tim ditantang mengeksplorasi solusi transportasi untuk tantangan energi masa kini dan masa depan.

Contoh (22) - (28) yang memuat hubungan jussive ini dihasilkan oleh adanya penggunaan verba menyuruh, membantah, melarang, mengancam, dilarang, didakwa, dan ditantang pada aktivitas pertama. Verba ini membentuk konstruksi deret verba yang kemudian menghasilkan konstruksi kosubordinasi dalam bahasa Indonesia. Meskipun seakan terlihat sejajar, tetapi aktivitas kedua merupakan bagian dari aktivitas pertama.

Aktivitas kedua pada contoh (22) mengubah aturan yang telah disepakati menunjukkan perintah dari apa yang disebutkan pada aktivitas pertama, Dialah yang menyuruh. Aktivitas kedua pada contoh (23) menerima uang dari Kepala Balai Pelaksanaan Jalan Nasional (BPJN) IX Provinsi Maluku dan Maluku Utara (Malut) Amran HI Mustary menunjukkan hubungan tuntutan dari apa yang disebutkan pada 
aktivitas pertama, Begitu juga dengan Direktur Jalan Bebas Hambatan Direktorat Jenderal Bina Marga Subagyo yang membantah. Aktivitas kedua pada contoh (24) memungut iuran kebersihan dari pengurus $R T$ dan $R W$ menunjukkan hubungan larangan dari apa yang disebutkan pada aktivitas pertama, Sebagai pejabat, ia melarang. Aktivitas kedua pada contoh (25) mengubah ideologi Pancasila menunjukkan hubungan ancaman dari apa yang disebutkan pada aktivitas pertama. Aktivitas kedua pada contoh (26) menerima honor dari pihak swasta menunjukkan hubungan larangan dari apa yang disebutkan pada aktivitas pertama. Aktivitas kedua pada contoh (27) menyiapkan catatan medis palsu agar Novanto bisa dirawat menunjukkan hubungan dakwaan dari aktivitas pertama. Aktivitas kedua pada contoh (28) mengeksplorasi solusi transportasi untuk tantangan energi masa kini dan masa depan menunjukkan hubungan permintaan dari aktivitas pertama. Deretan aktivitas pada contoh-contoh tersebut seakan terlihat sejajar, tetapi aktivitas kedua merupakan bagian dari aktivitas pertama.

\section{Hubungan Propositional Attitude (Penyikapan Awal)}

Hubungan penyikapan awal merupakan hasil ekspresi partisipan dalam menyikapi suatu keputusan atau pendapat tentang suatu peristiwa tertentu. Aktivitas pertama merupakan sikap yang ditunjukkan oleh partisipan, sedangkan aktivitas kedua merupakan hasil dari sikap tersebut. Aktivitas pertama dan aktivitas kedua dibentuk oleh deret verba yang terbangun secara kosubordinasi. Dari penelusuran data, ditemukan beberapa verba dalam bahasa Indonesia yang berpotensi memuat hubungan makna penyikapan awal. Verba tersebut adalah memilih, berjanji, berharap, meyakini, mengaku, meyakinkan, tertarik, diharapkan, diizinkan, dan diklaim. Bentuk ini ditemukan sebanyak $21,87 \%$. Berikut ini adalah beberapa contoh penggunaan hubungan penyikapan awal.

(29) Akibatnya, kini banyak warga memilih memakai mesin pembangkit listrik.

(30) Ia berjanji mengirim konvoi bantuan kemanusiaan ke Ghouta Timur.

(31) Dalam pembacaan tuntutan di Pengadilan Tindak Pidana Korupsi Jakarta, Kamis (8/3), Subari Kurniawan, jaksa KPK, mengatakan, Nur Alam telah terbukti meyakinkan melakukan tindak pidana korupsi melalui penerimaan suap dalam penerbitan izin usaha pertambangan (IUP).

(32) Saat memberikan sambutan, Sinta mengaku mendapatkan suntikan semangat yang luar biasa.

(33) Besarnya dana ini menjadikan pejabat pemerintah daerah tertarik mencari keuntungan. 
(34) Pola itu diyakini mengasah kompetensi kepribadian dan sosial guru sebelum terjun ke sekolah.

Contoh (29) - (34) yang memuat hubungan Prepositional Attitude ini dihasilkan oleh adanya penggunaan verba pada aktivitas pertama dan aktivitas kedua. Peristiwa memakai mesin pembangkit listrik pada contoh (29) merupakan putusan dari banyak warga memilih. Peristiwa mengirim konvoi bantuan kemanusiaan ke Ghouta Timur pada contoh (30) merupakan putusan dari aktivitas Ia berjanji. Peristiwa melakukan tindak pidana korupsi melalui penerimaan suap dalam penerbitan izin usaha pertambangan (IUP) pada contoh (31) merupakan ekspresi sikap partisipan dari verba meyakinkan. Peristiwa mendapatkan suntikan semangat yang luar biasa pada contoh (32) merupakan ekspresi sikap partisipan dari verba mengaku. Peristiwa mencari keuntungan pada contoh (33) merupakan ekspresi sikap partisipan dari verba tertarik. Peristiwa mengasah kompetensi kepribadian dan sosial guru sebelum terjun ke sekolah pada contoh (34) merupakan ekspersi sikap yang diyakini oleh partisipan.

Deret verba yang terdapat pada beberapa contoh tersebut terhubung secara kosubordinasi. Artinya, aktivitas pertama seakan-akan sejajar dengan aktivitas kedua, tetapi aktivitas kedua tak bisa dilepaskan dari aktivitas pertama.

\section{Hubungan Cognition (Kognisi): Ekspresi Pengetahuan dan Aktivitas mental}

Hubungan ini menggambarkan suatu ekspresi kognitif atau ekspresi pengetahuan yang ada dalam pikiran partisipan. Biasanya, verba yang digunakan pada aktivitas pertama merupakan tindakan yang berhubungan dengan kognisi manusia, seperti berpikir, mengetahui, merasa dsb. Penggunaan bentuk ini ditemukan sebanyak 9,37\%. Berikut ini contoh yang menunjukkan hubungan kognisi.

(35) Para koruptor itu berpikir membohongi masyarakat Indonesia.

(36) Pemain Juventus merasa memikul tanggung jawab lebih tanpa kehadiran ketiga pemain tersebut.

Contoh (35) dan (36) memuat hubungan kognisi. Hubungan ini dihasilkan oleh adanya penggunaan verba berpikir pada kalimat (35) dan merasa pada kalimat (36). Verba ini berpotensi membentuk konstruksi deret verba: berpikir membohongi pada kalimat (35) dan merasa memikul pada kalimat (36). Deret verba ini menghasilkan dua aktivitas yang terhubung secara kosubordinasi. 


\section{Hubungan Indirect Perception (Persepsi Tidak Langsung)}

Hubungan persepsi tidak langsung merupakan proses deduksi atau penyimpulan dari beberapa tindakan, kejadian, atau situasi berdasarkan bukti yang tak dilihat secara langsung. Proses deduksi itu melibatkan rasionalisasi dari bukti yang ada. Penelusuran terhadap data menunjukkan bahwa deretan verba bermuatan persepsi tidak langsung yang ditemukan: dianggap terbukti menerima, terbukti melanggar. Hubungan berjenis ini ditemukan sebanyak 7,3\%. Berikut ini contoh konstruksi kosubordinasi bermuatan hubungan persepsi tidak langsung.

(37) Gubernur Sulawesi Tenggara (nonaktif) dianggap terbukti menerima suap dalam penerbitan izin usaha pertambangan nikel untuk PT Anugrah Harisma Barakah di Pulau Kabena, Sultra.

(38) NA terbukti melanggar Pasal 2 Ayat 1 juncto Pasal 18 Undang-Undang Nomor 20 tahun 2001 tentang Tindak Pidana Korupsi jo Pasal 55 ayat 1 ke-1 Kitab Undang-Undang Hukum Pidana (KUHP).

Contoh (37) - (38) memuat adanya hubungan bermuatan persepsi tidak langsung. Hubungan ini ditunjukkan oleh adanya pertautan proses deduksi dalam verba pertama dan verba kedua. Pada contoh (37), aktivitas kedua, menerima suap dalam penerbitan izin usaha pertambangan nikel untuk PT Anugrah Harisma Barakah di Pulau Kabena, Sultra, adalah hasil dari proses deduksi pada verba dianggap terbukti. Pada contoh (38), aktivitas kedua, melanggar Pasal 2 Ayat 1 juncto Pasal 18 UndangUndang Nomor 20 tahun 2001 tentang Tindak Pidana Korupsi jo Pasal 55 ayat 1 ke-1 Kitab Undang-Undang Hukum Pidana (KUHP) merupakan proses deduksi dari verba terbukti. Konstruksi ini bersifat kosubordinasi karena terlihat sejajar, tetapi sebenarnya bersifat subordinasi.

\section{PENUTUP}

Kosubordinasi merupakan rangkaian aktivitas berurutan dari suatu konstruksi yang dilakukan oleh partisipan. Hubungan dalam kosubordinasi menyerupai koordinasi, tetapi masing-masing konstruksi itu tidak dapat berdiri sendiri sebagai suatu klausa bebas karena klausa yang satu terikat pada yang lain. Relasi makna yang ditemukan di dalam konstruksi kosubordinasi bahasa Indonesia di antaranya (1) tujuan sebesar 23,95\%, (2) penyikapan awal sebesar 21,87\%, (3) jussive (ekspresi perintah, permintaan, atau tuntutan) sebesar 14,6\%, (4) wacana tidak langsung sebesar 12,5\%, (5) fase sebesar 10,41\%, (6) kognisi sebesar 9,37\%, (7) persepsi tidak langsung sebesar 
7,3\%. Temuan ini menunjukkan bahwa relasi semantik yang paling banyak digunakan adalah relasi semantik tujuan. Hal ini disebabkan oleh adanya kemampuan verba berfitur relasi "tujuan" untuk hadir secara bersama dengan beberapa verba lain tanpa konjungsi. Oleh karena itu, dibutuhkan studi lanjutan untuk melihat kemampuan setiap verba berderet dengan verba yang lain dalam satu konstruksi.

\section{DAFTAR PUSTAKA}

Anwar, Miftahulkhairah dan Sakura. (2014). Sintaksis:Memahami Satuan Kalimat Perspektif Fungsi. Jakarta: Bumi Aksara.

Anwar, Miftahulkhairah. (2012). "Kalimat Majemuk dan Representasi Semantiknya". Jurnal Kekelpot. Kementerian Pendidikan dan Kebudayaan Balai Bahasa Banda Aceh. Volume 8, Agustus.

Anwar, Miftahulkhairah. (2010). "Asumsi-Asumsi Linguistik Fungsional Bagi Pengajaran Sintaksis" dalam Bunga Rampai Idiosinkrasi Pendidikan Karakter Melalui Bahasa dan Sastra. Yogyakarta: Kepel Press.

Alwi, Hasan, dkk. (2003). Tata Bahasa Baku Bahasa Indonesia Edisi Ketiga. Jakarta: Badan Pengembangan dan Pembinaan Bahasa, Kementrian Pendidikan dan Kebudayaan.

Arifin, Zaenal dan Junaiyah. (2009). Sintaksis. Jakarta: Grasindo.

Achmad, H.P. Sintaksis. (2002). Sintaksis Bahasa Indonesia. Jakarta: Manasco Offset.

Belyaev, Oleg. (2015). "Systematic mismatches: Coordination and subordination at three levels of grammar". Journal of Linguistics. Cambridge: Cambridge University Press. Vol. 51, issue 2, hal. 267.

Caesar, Regina Oforiwah. (2016). "Serial Verb Constructions in Dangme". Journal of Literature, Languages, and Linguistics. Vol. 20, hal. 20.

Chaer, Abdul. (2009). Sintaksis Bahasa Indonesia (Pendekatan Proses). Jakarta: Rineka Cipta.

Firdaus, Winci. (2018). "Ralisasi Pronomina dalam Bahasa Mooi: Ranah : Jurnal Kajian Bahasa, Vol. 7, No.2, hal 181.

Moeliono, Anton, dkk. (2017). Tata Bahasa Baku Bahasa Indonesia Edisi Keempat. Jakarta: Badan Pengembangan dan Pembinaan Bahasa Kementerian Pendidikan dan Kebudayaan.

Parera, J.D. (2009). Dasar-Dasar Analisis Sintaksis. Jakarta: Erlangga.

Putrayasa, Ida Bagus. (2007). Analisis Kalimat: Fungsi, Peran, dan Kategori. Bandung: Refika Aditama.

Ramlan. (2008). Kalimat, Konjungsi, dan Preposisi Bahasa Indonesia dalam Penulisan Karangan Ilmiah. Yogyakarta: Universitas Sanata Dharma.

Valin, Van R.D. (2005). A Summary of Role and Reference Grammar. Berlin: Mouton de Gruyter. [earlier version available on RRG web site under the title 'On the relationship between syntactic theory and models of language processing']

Valin, Van R.D. and Randy Lapolla. (1997). Syntax: Structure, Meaning, and Function. Cambridge University Press

Valin, Van R. D. (2005). Exploring the syntax-semantics interface. Cambridge: Cambridge University Press.

Valin, Van R. D. Jr. (2001). "Functional Linguistic" dalam The Hand Book of Linguistics. USA: Black Well Publisher. 